\title{
Analysis of the power production of a Wind farm with consumption associated for desaled water for agriculture, in Gran Canaria
}

\author{
A. Pulido, J.Lozano ${ }^{*}$, N. Angulo, J. Romero, L.Darias \\ Dpto. de Ingeniería Eléctrica. \\ Universidad de Las Palmas de Gran Canaria \\ Campus Universitario de Tafira. 35017 Las Palmas de Gran Canaria (Islas Canarias) \\ Tel.:+34 928 451987, e-mail: apulido@die.ulpgc.es
}

(*) Soslaires Canarias, SL

\section{Troubles about water in the World}

The amount of water collects and keeps in reservoir is the quadruplet from 1960, and the amount of water contained in dams is six or three greater than the one of the natural rivers. The water taking from the rivers and lakes has been duplicated from 1960; the most of it $(70 \%$ at world-wide level) is destined to agriculture.

The number of species on planet is diminishing. In the last centuries, the human beings have made increase the rate of extinction of species up to 1,000 times over the typical rates of history of the planet (average certainty). Between the 10 and 30\% of the species of mammals, birds and amphibians at the moment. In general, the fresh water habitat tends to have the highest proportion of threatened species of extinction.

Perhaps from the 5 to $25 \%$ of world-wide the fresh water use it exceeds the accessible provisions in the long term and now it is obtained by means of trasvases of water with engineer installations or by means of the underground water consumption over the replacement levels.

Around the 15 to $35 \%$ of the water used for irrigation it exceeded the rates provision and, therefore, the consumption is untenable (low certainty to average).

Half of the urban population of Africa, Asia, Latin America and the Caribbean undergoes one or more diseases related to the insufficiency of the water provision and the cleaning.

Approximately 1.7 million people die annually anywhere in the world because of the shortage of water, cleaning and hygiene.

One of the eight Objectives of Development of the Millenium adopted by the Nations United in 2000 is reduce the infantile mortality. The bad nutrition is the underlying cause of an important proportion of all the infantile deaths, but also strongly is influenced by the diseases associated with the quality of the water. The diarrhoea is one of the predominant causes of infantile mortality anywhere in the world.[1]

\section{Associate Consumptions of the wind farm}

A reverse osmosis desalination plant for irrigable agricultural, with a production capacity of $5000 \mathrm{~m} 3 /$ day.
The desalted water feeds irrigable of the same company with its associated elements of pumping, and others to which the served water. Contracted Tarifa of the consumed electricity of the network is R.1. agriculture. This is because the desalination installation does not use any additive, the only thing that is made is the pumping and filtrate water, reason why can not be considered like an industrial process. The average price of year 2005 was of 6.9425 cent $€ / \mathrm{kWh}$ is very expensive, but the power term is cheap 50,629 cent $€ / \mathrm{kW} /$ month, it is the best solution [5]. The sale price of the desalted water is approximately 60 cent $€ / \mathrm{m}^{3}$, in the year, and the production during about $800,000 \mathrm{~m}^{3}$.

In this year the average price of sale of electricity was aprox. 7 cent€ $/ \mathrm{kWh}$. The plant have a very elevated efficiency, due to its interchanger pressure of ceramic, to over sizing of the filters and the other hydraulic devices, which allows to use minor speed in pipes, in addition the use to centrifugal pumps of camera divided fed with speed variators, with it and other considerations is obtained an exclusive design, the specific electrical consumption is reduced to $2.8 \mathrm{kWh} / \mathrm{m}^{3}$. Which is describe next:

- Feeding (pumping water of sea, $20 \mathrm{~m}$ ): $0.4 \mathrm{Kwh} / \mathrm{m}^{3}$

- Process (pumping high pressure): $1.9 \mathrm{Kwh} / \mathrm{m}^{3}$

- Elevation (until consumption point): $0.3 \mathrm{Kwh} / \mathrm{m}^{3}$ Distances: 3,6km/Level: $90 \mathrm{~m}$

- Associated loads:

Productions days:

$0.2 \mathrm{Kwh} / \mathrm{m}^{3}$

Total annual consumption:

$350 \mathrm{~d} / \mathrm{año}$

4.900.000 Kwh.

In front of a plant of conventional design with recovery of energy by means of a turbine pelton, whose specific consumption would be of $4.8 \mathrm{kWh} / \mathrm{m} 3$

- Feeding (pumping water of sea):

$0.5 \mathrm{Kwh} / \mathrm{m}^{3}$

- Process (pumping high pressure): $\quad 3.9 \mathrm{Kwh} / \mathrm{m}^{3}$

- Elevation (until consumption point): $0.3 \mathrm{Kwh} / \mathrm{m}^{3}$ Distances: 3,6km/Level: $90 \mathrm{~m}$

- Associated Aids and:

$0.1 \mathrm{Kwh} / \mathrm{m}^{3}$

Productions Days:

Total annual consumption:

8.400.000 Kwh 


\section{Wind farm description}

The Farm is formed by four units Gamesa G47- $660 \mathrm{~kW}$, adding a power of $2.64 \mathrm{MW}$. Inaugurated in June of 2002. Generating asynchronous they are doubly fed, using technology IGBT in its stage of power. They count on a close control of reactive, fit to obtain a power factor unit, and guarantees a low presence of overvoltage. The characteristics of these units are the following ones:

$\begin{array}{lll}\text { - } & \text { Diameter. } & 47 \mathrm{~m} \\ \text { - } & \text { Nominal power. } & 660 \mathrm{~kW} \\ \text { - } & \text { Speed turn: } & 22,8 \div 30.9 \\ \text { - } & \text { Nominal voltage } & 690 \mathrm{~V} \\ \text { - Nominal current } & 557,9 \mathrm{~A} \\ \text { - } & \text { Area of sweeping: } & 1735 \mathrm{~m}^{2}\end{array}$

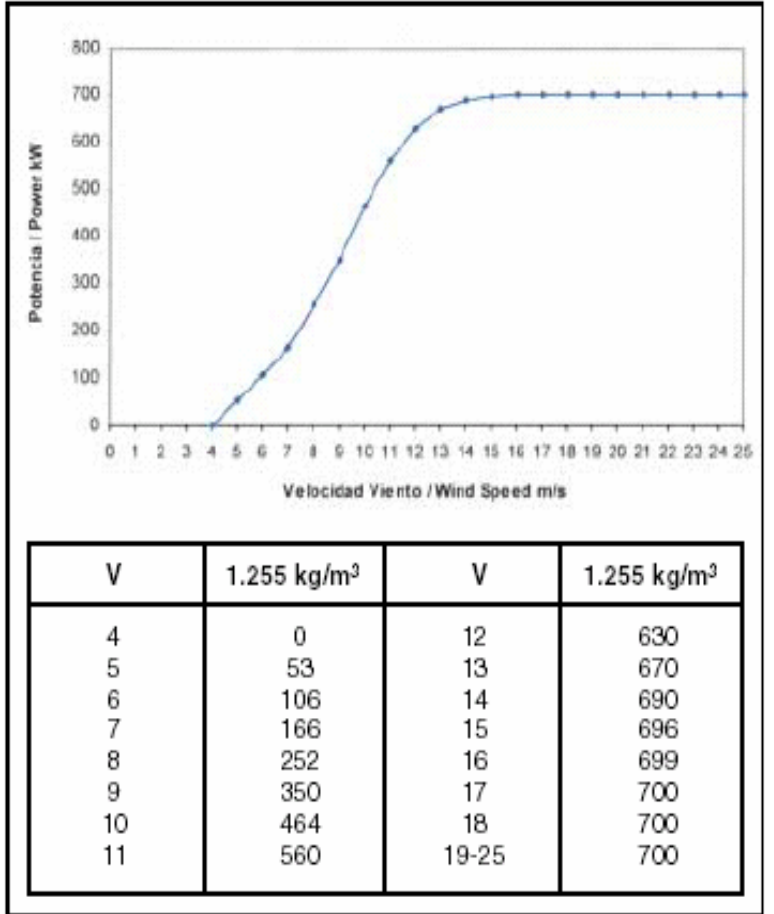

\section{Analysis of years 2004 and 2005}

The number of equivalent hours of year 2004, is of 3608 hours. In the present year to date of today it is surpassed the production. In the month of July of this year the use factor is $77,5 \%$ The results of energy produced, bought, consumed by itself, and sold during year 2004 are to month and 2005 until today. This is observed that in the year the consumption is only of $37.1 \%$ of the production, is because the production considered by the previous construction widely has been surpassed and that the implemented measures of power saving in the plant have diminished enormously the cost of desalination. With which it is fulfilled the selfproducer definition according to R.D. 436/2004, but it fails to fulfill with decree $53 / 2003$, of 30 of April, by that one regulates the installation and operation of the wind farms in the scope of the Community of the Canary Islands, in his article 8 on facilities with associated consumptions, in which the following thing in the second section is considered: The Wind farm with consumptions associate will be able to spill to the energy network their excessive until a maximum limit of $50 \%$ of the energy generated measurement in annual average.

It is obvious the free and seasons variability of the resource in study.

\begin{tabular}{||lrrrr||}
\hline \multirow{2}{*}{ kWh } & \multicolumn{2}{c}{ Producción } & \multicolumn{2}{c|}{ Vendida } \\
& 2004 & 2005 & 2004 & 2005 \\
Enero & 463980 & 247067 & 288771 & 94951 \\
Febrero & 332260 & 411490 & 193273 & 291392 \\
Marzo & 991698 & 398115 & 764636 & 253628 \\
Abril & 457700 & 1062989 & 324621 & 799127 \\
Mayo & 883829 & 1115493 & 739191 & 859494 \\
Junio & 1245538 & 1216483 & 1058484 & 882719 \\
Julio & 1523152 & 1500172 & 1283436 & 1210087 \\
Agosto & 1078426 & 1344834 & 858496 & 996749 \\
Septiembre & 1101667 & & 750403 & \\
Octubre & 365314 & & 152860 & \\
Noviembre & 317496 & & 120956 & \\
Diciembre & 763780 & & 511880 & \\
Enero-Agosto & 6976583 & 7296643 & 5510908 & 5388147 \\
Total Año & 9524840 & & 7047007 & \\
\hline \hline
\end{tabular}

\begin{tabular}{||lrrrr||}
\hline kWh & \multicolumn{2}{c|}{ Comprada } & \multicolumn{2}{c||}{ Autoconsumida } \\
& 2004 & 2005 & 2004 & 2005 \\
Enero & 91273 & 194665 & 175209 & 152116 \\
Febrero & 160013 & 74544 & 138987 & 120098 \\
Marzo & 69489 & 141185 & 227062 & 144487 \\
Abril & 67766 & 39576 & 133079 & 263862 \\
Mayo & 41474 & 44743 & 144638 & 255999 \\
Junio & 13219 & 39208 & 187054 & 333764 \\
Julio & 2808 & 22038 & 239716 & 290085 \\
Agosto & 23185 & 8522 & 219930 & 348085 \\
Septiembre & 50343 & & 351264 & \\
Octubre & 223558 & & 212454 & \\
Noviembre & 214998 & & 196540 & \\
Diciembre & 98480 & & 251900 & \\
Enero-Agosto & 469227 & 564481 & 1465675 & 1908496 \\
Total Año & 1056606 & & 2477833 & \\
\hline \hline
\end{tabular}

\section{Analysis of sold energy in july of $\mathbf{2 0 0 5}$}

In the pages that are accompanied they enclose the listing of production in each hour strip throughout the mentioned month, when entering the page Web of the Operator of the Iberian Market, in the table of the mentioned month we unloaded the leaf of Excel with the prices, with the object of had in the Transitory Disposition $2^{\text {a }}$ Real Decree 436/2004 elaborated in agreement with the calculation method of the economic regime transitory derivative of Real Decree 2818/1998. Multiplying the production of each cell (hour strip), by its price we obtain the table of amounts by production in euros. Starting off of the data of hour production of 2005 July and of the leaf of prices obtained of omel, a series of conclusions is obtained.

Exist hours in which the generation gets to exceed the nominal power of the farm, the maximum production 
agrees with the rush hours, the starting management and shutdown of the osmosis plant would have to obey to the valley hours.

\section{An analysis of diferent rates}

An analysis of the different tariffs from which we could be get according to the present legislation, obtaining like conclusion that it is without a doubt, the most interesting. Tying the renewable energies to the water production could finish with a lot of the problems which today the international community faces.

\section{References}

[1] Evaluación de los Ecosistemas del Milenio. Elaborado por la ONU. 2005

[2] La desalación como alternativa al Plan Hidrológico Nacional. Elaborado por el Gobierno de Aragón. 2001

[3] Canarias 7. Jueves 23 de septiembre de 2004. fuente el I.T.C.

[4] Real Decreto 436/2004, de 12 de marzo, por el que se establece la metodología para la actualización y sistematización del régimen jurídico y económico de la actividad de producción de energía eléctrica en régimen especial

[5] Real Decreto 2392/2004, de 30 de diciembre, por el que se establece la tarifa eléctrica para 2005.

[6] Decreto 53/2003, de 30 de abril, por el que se regula la instalación y explotación de los parques eólicos en el ámbito de la Comunidad Autónoma de Canarias 
Ejemplo de Factura:

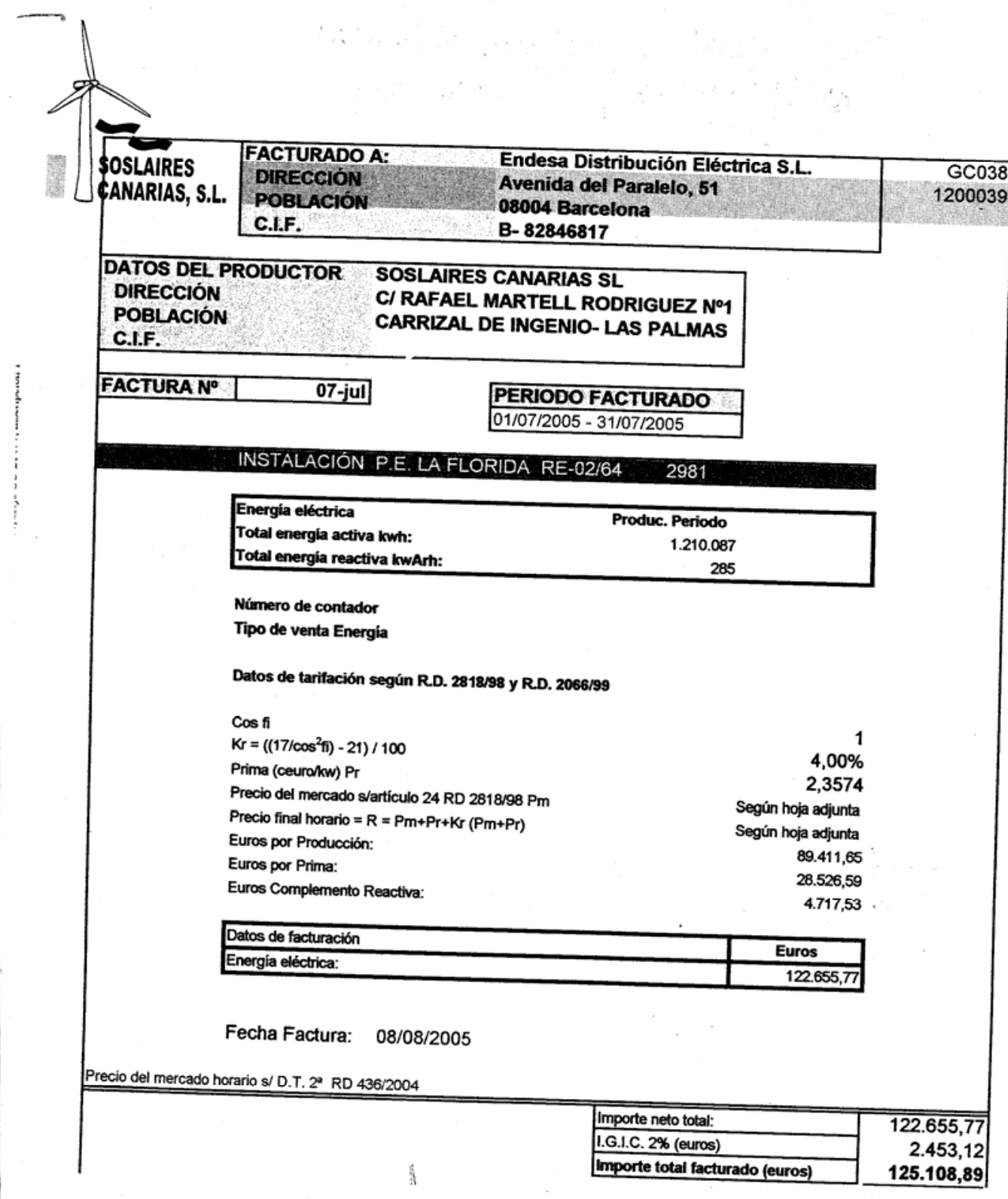


Tabla de Producción que la acompaña:

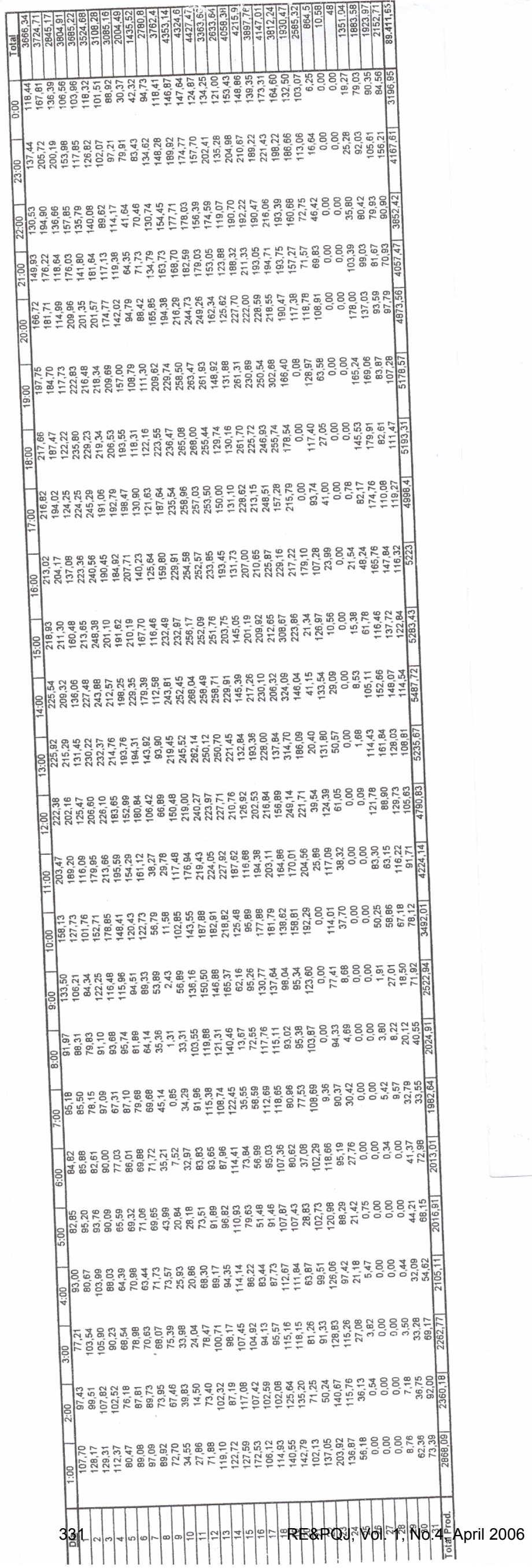


Tabla de euros, por horas resultado de multiplicar la tabla ofrecida por Omel y la de producción.

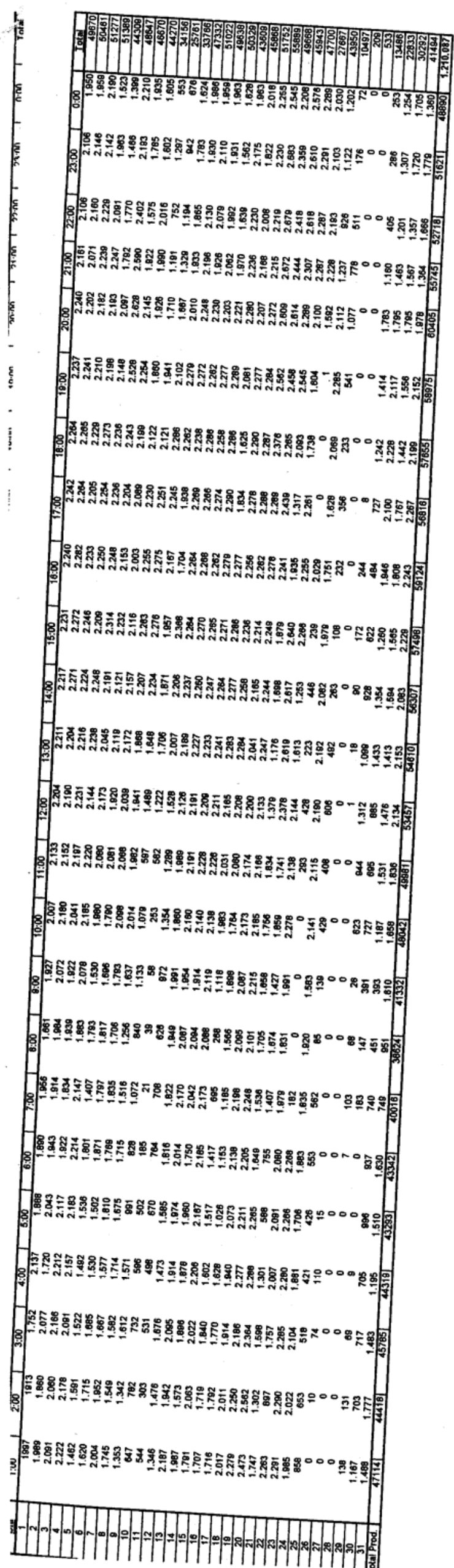

